\title{
Single Cystosorus Isolate Production and Restriction Fragment Length Polymorphism Characterization of the Obligate Biotroph Spongospora subterranea f. sp. subterranea
}

\author{
Xinshun Qu and Barbara J. Christ
}

Department of Plant Pathology, The Pennsylvania State University, University Park 16802. Accepted for publication 4 May 2006.

\begin{abstract}
Qu, X. S., and Christ, B. J. 2006. Single cystosorus isolate production and restriction fragment length polymorphism characterization of the obligate biotroph Spongospora subterranea f. sp. subterranea. Phytopathology 96:1157-1163.

Spongospora subterranea f. sp. subterranea causes powdery scab in potatoes and is distributed worldwide. Genetic studies of this pathogen have been hampered due, in part, to its obligate parasitism and the lack of molecular markers for this pathogen. In this investigation, a single cystosorus inoculation technique was developed to produce large amounts of S. subterranea f. sp. subterranea plasmodia or zoosporangia in eastern black nightshade (Solanum ptycanthum) roots from which DNA was extracted. Cryopreservation of zoosporangia was used for long-term storage of the isolates. S. subterranea f. sp. subterranea-specific restriction fragment length polymorphism (RFLP) markers were developed from

The fragments were screened for specificity by Southern hybridization and subsequent DNA sequence BLAST search. Four polymorphic $S$. subterranea f. sp. subterranea-specific probes containing repetitive elements, and one containing single copy DNA were identified. These RFLP probes were then used to analyze 24 single cystosorus isolates derived from eight geographic locations in the United States and Canada. Genetic variation was recorded among, but not within, geographic locations. Cluster analysis separated the isolates into two major groups: group I included isolates originating from western North America, with the exception of those from Colorado, and group II included isolates originating from eastern North America and from Colorado. The techniques developed in this study, i.e., production of single cystosorus isolates of $S$. subterranea f. sp. subterranea and development of RFLP markers for this pathogen, provide methods to further study the genetic structure of $S$. subterranea $\mathrm{f}$. sp. subterranea.
\end{abstract} randomly amplified polymorphic DNA (RAPD) fragments. Cystosori of $S$. subterranea f. sp. subterranea were used for RAPD assays and putative pathogen-specific RAPD fragments were cloned and sequenced.
Additional keyword: plasmodiophorid.
Spongospora subterranea (Wallr.) Lagerh f. sp. subterranea Tomlinson, causal agent of potato powdery scab, is a soilborne obligate pathogen and a plasmodiophorid (19). The pathogen causes powdery lesions on the skin of potato tubers, significantly reducing tuber quality and marketability. In addition, the pathogen may serve as a vector of Potato mop-top virus (PMTV) (18), which causes a reduction in growth of plants and induces internal tuber necrosis, and which has recently been found in the United States (23).

S. subterranea f. sp. subterranea can only multiply within living tissues of a host plant due to its obligate parasitic nature. It may survive as cystosori consisting of a spongy aggregate of resting spores, on tubers or in the soil. In the presence of a host, and under moist soil conditions and relatively low temperatures (12 to $18^{\circ} \mathrm{C}$ ), resting spores may geminate to produce primary biflagellate zoospores. The primary zoospores infect host plant root hairs and epidermal cells, and develop into multinucleate plasmodia that eventually cleave into segments to form zoosporangia. The germinating zoosporangia release secondary zoospores, which infect roots, stolons, and tubers of potato plants, resulting in powdery scab lesions on tubers and galls on roots and stolons $(19,33)$.

Control of powdery scab of potato is difficult because of the persistence of cystosori in soil (7). To date, all commercial potato cultivars screened are susceptible (13). With the lack of registered chemical fungicides and cultural management practices effective

Corresponding author: B. J. Christ; E-mail address: ebf@psu.edu

DOI: 10.1094/PHYTO-96-1157

(c) 2006 The American Phytopathological Society against this pathogen, the development of resistant cultivars is probably the most economical and cost effective method of controlling the disease.

Successful breeding and effective deployment of powdery scab resistant potato cultivars requires an understanding of the pathogen population structure and genetic diversity. However, the genetic variation of, and existence of pathotypes within $S$. subterranea $\mathrm{f}$. sp. subterranea populations has not yet been demonstrated (13). Detection of pathogenic variation of a plant pathogen has traditionally relied upon the identification of variation in virulence by inoculating isolates of the pathogen onto a series of host cultivars and observing the resulting disease phenotypes. However, it is difficult to apply this approach to $S$. subterranea $\mathrm{f}$. sp. subterranea for the following reasons: (i) obtaining and maintaining inoculum is difficult because of the obligate parasitic nature of the pathogen, (ii) no method is currently available for isolation of the pathogen from a single cystosorus, (iii) development of powdery scab is significantly influenced by environmental conditions $(15,42)$, and (iv) standard inoculation procedures and reference cultivars have not been established. A few field trials have been carried out to assess variation in virulence of $S$. subterranea $\mathrm{f}$. sp. subterranea, but no conclusive evidence for the existence of pathotypes was found $(3,20,47)$.

Recently, two ribosomal RNA internal transcribed spacer (ITS) sequence types (I and II) of S. subterranea f. sp. subterranea were identified in Australia and Europe (4,35), whereas North American isolates consisted of only one type (II) of ITS sequence (35). Because ITS sequence analysis relies on only one locus for detecting genetic variation, analyses with molecular markers that cover different parts of the pathogen genome are required to de- 
velop a comprehensive picture of the genetic variation and population structure of $S$. subterranea $\mathrm{f}$. sp. subterranea. Polymerase chain reaction (PCR)-based molecular markers, such as randomly amplified polymorphic DNA (RAPD) markers and amplified fragment length polymorphism (AFLP) markers, have been used to study genetic diversity in many plant pathogens. However, no such markers are available for $S$. subterranea f. sp. subterranea. The pathogen has not been cultured apart from its host, and the only form of the pathogen found outside of host plants is cystosori, which may also contain host plant tissues or be contaminated with secondary bacteria. It is therefore difficult to obtain pure DNA of the pathogen, a necessary step to develop and apply PCR-based markers.

Restriction fragment length polymorphism (RFLP) markers are co-dominant and locus-specific (25). They have been used extensively to assess the genetic diversity of plant pathogens $(44,48)$. Although more time consuming than PCR-based methods, RFLP methods are more reproducible and less sensitive to contaminating DNA than PCR-based assays $(40,45)$. Because RFLP markers have been developed successfully and used to analyze the genetic variation of other obligate plant pathogens, such as Peronospora tabacina Adam (40) and Plasmodiophora brassicae Woronin $(10,21)$, developing polymorphic RFLP markers for $S$. subterranea f. sp. subterranea should be possible. However, RFLP assays require relatively large amounts of DNA $(25,48)$. In an RFLP analysis of Plasmodiophora brassicae, the low yield of DNA from the obligate pathogen was overcome by extracting DNA from young diseased roots of Brassica rapa L. (21). In an investigation of the host range of S. subterranea f. sp. subterranea, eastern black nightshade (Solanum ptycanthum Dun.) (referred to hereafter as nightshade) was identified as a very susceptible host of the pathogen (36). It may be possible to inoculate nightshade with a single cystosorus of the pathogen, and subsequently extract DNA from the infected roots which have a large amount of S. subterranea f. sp. subterranea plasmodia or zoosporangia.

This paper describes the production of single cystosorus isolates of $S$. subterranea f. sp. subterranea using nightshade

TABLE 1. Sources of Spongospora subterranea f. sp. subterranea single cystosorus isolates and their restriction fragment length polymorphism (RFLP) groups and genotypes

\begin{tabular}{|c|c|c|c|c|}
\hline Isolate & Geographic origin & $\begin{array}{c}\text { Year of } \\
\text { collection }\end{array}$ & $\begin{array}{l}\text { RFLP } \\
\text { group }^{\text {a }}\end{array}$ & $\begin{array}{c}\text { RFLP } \\
\text { genotype }^{b}\end{array}$ \\
\hline CA-1 & California, USA & 2000 & I & A \\
\hline CA-2 & California, USA & 2000 & I & A \\
\hline CA-3 & California, USA & 2000 & I & A \\
\hline $\mathrm{CO}-1$ & Colorado, USA & 1999 & II & $\mathrm{B}$ \\
\hline $\mathrm{CO}-2$ & Colorado, USA & 1999 & II & B \\
\hline $\mathrm{CO}-3$ & Colorado, USA & 1999 & II & $\mathrm{B}$ \\
\hline ID-1 & Idaho, USA & 2000 & I & $\mathrm{C}$ \\
\hline ID-2 & Idaho, USA & 2000 & I & $\mathrm{C}$ \\
\hline ID-3 & Idaho, USA & 2000 & I & $\mathrm{C}$ \\
\hline ME-1 & Maine, USA & 1996 & II & $\mathrm{D}$ \\
\hline ME-2 & Maine, USA & 1996 & II & $\mathrm{D}$ \\
\hline $\mathrm{ME}-3$ & Maine, USA & 1996 & II & $\mathrm{D}$ \\
\hline NB-1 & New Brunswick, Canada & 2002 & II & $\mathrm{D}$ \\
\hline NB-2 & New Brunswick, Canada & 2002 & II & $\mathrm{D}$ \\
\hline NB-3 & New Brunswick, Canada & 2002 & II & $\mathrm{D}$ \\
\hline ND-1 & North Dakota, USA & 2002 & $\mathrm{I}$ & $\mathrm{E}$ \\
\hline ND-2 & North Dakota, USA & 2002 & I & $\mathrm{E}$ \\
\hline ND-3 & North Dakota, USA & 2002 & I & $\mathrm{E}$ \\
\hline PA-1 & Pennsylvania, USA & 2000 & II & $\mathrm{D}$ \\
\hline PA-2 & Pennsylvania, USA & 2000 & II & $\mathrm{D}$ \\
\hline PA-3 & Pennsylvania, USA & 2000 & II & $\mathrm{D}$ \\
\hline WA-1 & Washington, USA & 2000 & I & $\mathrm{F}$ \\
\hline WA-2 & Washington, USA & 2000 & I & $\mathrm{F}$ \\
\hline WA-3 & Washington, USA & 2000 & I & $\mathrm{F}$ \\
\hline
\end{tabular}

${ }^{a}$ Groups I and II were revealed by cluster analysis of RFLP data, as shown in Figure 2.

b Isolates with identical RFLP patterns have the same genotype. seedlings, and the development of $S$. subterranea f. sp. subterranea-specific polymorphic RFLP markers. This is the first attempt to study the genetic variation among single cystosorus isolates of $S$. subterranea f. sp. subterranea. The use of molecular markers to distinguish single cystosorus isolates of the pathogen genetically will facilitate further studies to determine the genetic structure of populations of $S$. subterranea f. sp. subterranea.

\section{MATERIALS AND METHODS}

Sources of $S$. subterranea f. sp. subterranea. Samples composed of potato tubers with powdery scab lesions were obtained from potato fields in each of seven U.S. states: Maine, California, Colorado, Washington, Idaho, North Dakota, and Pennsylvania; and one sample was obtained from New Brunswick, Canada (Table 1). These collections were selected based on geographic regions of potato production, powdery scab distribution, and the availability of samples. Each sample consisted of powdery scab tubers collected from one plant or different plants in one field. Cystosori were scraped from powdery scab lesions on washed tubers of each sample, macerated in a blender with $50 \mathrm{ml}$ of sterile distilled water (SDW) for $3 \mathrm{~min}$, and filtered through two layers of cheesecloth. The filtrate was centrifuged for $5 \mathrm{~min}$ at $1,700 \times g$ and washed five times in SDW by centrifugation. Cystosori were disinfested for $2 \mathrm{~h}$ at $25^{\circ} \mathrm{C}$ in the dark in an antibiotic solution containing $1 \mathrm{~g} /$ liter each of colistin sulfate, vancomycin hypochloride, and cefotaxime sodium. They were then washed twice in SDW by centrifugation, as described previously. Single cystosori were then removed from suspension by a previously published technique (38), in which a suspension of cystosori was spread on $1 \%$ agarose in a petri dish and single cystosori were located microscopically and picked up with a sterile scalpel.

Single cystosorus isolation and propagation. Seeds of nightshade were germinated in vermiculite at room temperature. At the two-leaf growth stage, seedlings were transferred to 30-ml plastic beakers (two seedlings per beaker) containing Merz's nutrient solution (28), wrapped with aluminum foil, and placed in an incubator with a $15-\mathrm{h} / 9$-h light/dark cycle at $18 / 15^{\circ} \mathrm{C}$. After 1 week, the two plants in each beaker were inoculated with one cystosorus. Fourteen days after inoculation, random subsamples of roots of the inoculated seedlings were excised and examined microscopically for the presence of S. subterranea f. sp. subterranea plasmodia or zoosporangia by staining the roots for $5 \mathrm{~min}$ in $1 \%$ cotton blue in lactophenol. Inoculum was then increased by transferring each of the infected seedlings that had zoosporangia in the root hairs to a new plastic beaker, which contained Merz's nutrient solution and two noninfected seedlings. The zoospores released from the infected seedling roots then infected the roots of the healthy seedlings. This transfer procedure was carried out every 4 days until $S$. subterranea $\mathrm{f}$. sp. subterranea plasmodia or zoosporangia were observed in most of the root hairs of nightshade seedlings, and DNA was subsequently extracted from the infected roots. The isolates were maintained indefinitely through serial transfers. Three single cystosorus isolates (designated as 1 , 2 , and 3) were obtained from different powdery scab tubers of the samples collected from each of the eight geographic locations, for a total of 24 single cystosorus isolates (Table 1). Healthy nightshade seedlings grown in nutrient solution were used as noninoculated treatments.

Cryopreservation of single cystosorus isolates. An optimal cryopreservation protocol using zoosporangia of $S$. subterranea $\mathrm{f}$. sp. subterranea as storage material and $10 \%$ glycerol as the cryoprotectant (X. S. Qu and B. J. Christ, unpublished data) was used in this study to store all isolates of $S$. subterranea $\mathrm{f}$. sp. subterranea. The entire infected nightshade root system with zoosporangia in the root hairs was suspended in $10 \%$ glycerol in a 1.8-ml Nalgene cryogenic vial (Nalge Company, Rochester, NY). 
The vial was then immersed in $100 \%$ isopropanol to provide a cooling rate of $1^{\circ} \mathrm{C} / \mathrm{min}$ when placed at $-20^{\circ} \mathrm{C}$. After overnight storage at $-20^{\circ} \mathrm{C}$, the vial was stored at $-80^{\circ} \mathrm{C}$.

Two isolates of $S$. subterranea f. sp. subterranea, PA-1 and NB-1, were used to assess whether cryopreserved zoosporangia could be viable after storage. Vials containing cryopreserved samples were thawed quickly by immersing the vials in water at $37^{\circ} \mathrm{C}$ for $1 \mathrm{~min}$ immediately after removal from storage at $-80^{\circ} \mathrm{C}$ for 1 week, 1 month, or 6 months. The thawed, infected nightshade roots were rinsed once in SDW to remove the glycerol and then used to inoculate healthy nightshade seedlings. The roots of the healthy nightshade seedlings were examined microscopically daily after inoculation for the presence of plasmodia or zoosporangia. This experiment was carried out three times, each time with three replicates of entire infected nightshade root systems for each of the two isolates.

DNA extraction. Total DNA was extracted from nightshade roots by a cetyltrimethylammonium bromide (CTAB) method (9), after the roots had been washed in running tap water. DNA was also extracted from S. subterranea f. sp. subterranea cystosori, potato leaves, and bacteria as described below, and was used to determine the specificity of $S$. subterranea $\mathrm{f}$. sp. subterranea probes. One hundred cystosori were removed from each of the suspensions of disinfested Pennsylvania and Idaho cystosori (treated with an antibiotic solution as described above) using a method described previously (38). DNA was extracted from each of the resultant pellets of cystosori by the method of Möller and Harling (30). Plants of potato cv. Katahdin were grown in plastic pots containing soilless mix in a greenhouse, and DNA was extracted from young leaves of the plants using the CTAB method (9). Since cystosori may be contaminated with bacteria, five cystosori were removed from a suspension of Pennsylvania cystosori that had not been treated with an antibiotic solution, transferred to a petri dish containing $4 \%$ potato dextrose agar (PDA), and incubated at $20^{\circ} \mathrm{C}$ in the dark. After 5 days, bacterial colonies observed in the immediate vicinity of the cystosori were subcultured onto 4\% PDA, and total DNA was extracted from the bacterial colonies by a method described previously (24). No attempt was made to identify the bacteria found in association with cystosori.

RAPD analysis. RAPD assays using 20 oligonucleotide primers (OPA01 to OPA20; Operon, Alameda, CA) were carried out with DNA from cystosori collected from Pennsylvania and Idaho tuber samples. DNA from bacteria and leaves of potato cv. Katahdin was used as controls since cystosori may be contaminated with bacteria or host tissues. RAPD amplifications were performed in $25-\mu \mathrm{l}$ reaction mixtures containing $1 \times$ PCR buffer (Applied Biosystems, Foster City, CA), $2 \mathrm{mM} \mathrm{MgCl}_{2}, 200 \mu \mathrm{M}$ of each dNTP, 5 pmol of each primer, 0.5 unit of AmpliTaq polymerase (Applied Biosystems), and 20 to $30 \mathrm{ng}$ of DNA template. Amplifications were carried out on a PTC-100-60 programmable Thermal Controller (MJ Research, Watertown, MA) with an initial cycle at $95^{\circ} \mathrm{C}$ for $2 \mathrm{~min}$ followed by 45 cycles at $95^{\circ} \mathrm{C}$ for $1 \mathrm{~min}, 36^{\circ} \mathrm{C}$ for $1 \mathrm{~min}$, and $72^{\circ} \mathrm{C}$ for $2 \mathrm{~min}$; and a final cycle at $72^{\circ} \mathrm{C}$ for $7 \mathrm{~min}$. All RAPD amplifications were performed at least three times to ensure reproducibility of results. RAPD products were separated by electrophoresis on $1.5 \%$ low melting point agarose (Invitrogen, Carlsbad, CA) gels containing ethidium bromide, and visualized with a UV transilluminator.

Cloning and sequencing of RAPD fragments. Putative $S$. subterranea f. sp. subterranea-specific RAPD bands were excised from the $1.5 \%$ agarose gel, purified with the QIAquick PCR Gel Purification Kit (QIAGEN, Valencia, CA), cloned in the pGEM-T Vector (Promega, Madison, WI), and transformed into E. coli JM109. Both strands of the RAPD fragments cloned in the plasmid were sequenced with an ABI PRISM BigDye Terminator Cycle Sequencing Ready Reaction Kit (Applied Biosystems). DNA sequences were determined using an ABI PRISM377 DNA sequencer (Applied Biosystems). Consensus sequences of RAPD fragments were obtained by comparing complementary strands using the SeqMan program in DNAStar (DNAStar Inc., Madison, WI). GenBank databases were searched using the BLASTn and BLASTx algorithms (1) to find homologous sequences.

Southern hybridization. The specificity of RAPD products as $S$. subterranea f. sp. subterranea probes was tested by Southern hybridization of PstI-digested DNA isolated from bacteria, potato, cystosori of Pennsylvania and Idaho tuber samples, healthy nightshade roots, and infected nightshade roots inoculated with each of isolates of PA-1 and ID-1. Following separation of the restricted DNA by electrophoresis in a $0.8 \%$ agarose gel, the DNA fragments were transferred to a Hybond $\mathrm{N}+$ membrane (Amersham Biosciences, Piscataway, NJ) using an alkali transfer procedure (Amersham Biosciences). Putative $S$. subterranea f. sp. subterranea-specific RAPD fragments were labeled with $\left(\alpha^{32} \mathrm{P}\right)$ dCTP using Ready-To-Go DNA Labeling Beads (Amersham Biosciences). Unincorporated labeled nucleotides were removed using ProbeQuant G-50 Micro Columns (Amersham Biosciences). Hybridization was performed at $65^{\circ} \mathrm{C}$ in hybridization buffer (0.5 $\mathrm{M} \mathrm{NaHPO}_{4}$ [pH 7.2], 1 mM EDTA [pH 8.0], 7\% sodium dodecyl sulfate, and $1 \%$ bovine serum albumin). Following hybridization, the membrane was washed and exposed to Kodak BioMax MS X-ray film (Kodak, Rochester, NY). Two restriction enzymes, EcoRI and PstI, and S. subterranea f. sp. subterraneaspecific probes were then used for RFLP analysis of the mixtures of host plant and pathogen DNA from each of the 24 isolates of the pathogen. Healthy nightshade DNA was used as a control.

Genetic analysis of RFLP data. RFLP bands were recorded binarily as present (1) or absent (0). Only unambiguous bands were scored to generate a data matrix. Genetic distances between all pairs of genotypes were calculated using the method of Nei and $\mathrm{Li}$ (32) with the PAUP program version 4.0b10 (Sinauer Associates, Sunderland, MA). Cluster analysis was carried out by the unweighted pair-group method with the arithmetic average (UPGMA) using PAUP. The strength of each cluster in the dendrogram was tested statistically by bootstrap analysis (11) with 1,000 replications.

\section{RESULTS}

Isolation and propagation of $S$. subterranea f. sp. subterranea from single cystosorus. Plasmodia or zoosporangia of $S$. subterranea f. sp. subterranea were observed in the root hairs of all nightshade seedlings 14 days after inoculation of the plants with single cystosori. When infected nightshade seedlings with zoosporangia in the root hairs were used to inoculate healthy nightshade seedlings, plasmodia or zoosporangia were observed in roots of the seedlings 3 to 4 days following inoculation. The results indicated that zoospores released from the roots of the infected seedling did infect healthy seedling roots. After three cycles of inoculations, plasmodia or zoosporangia were observed in most of the root hairs of nightshade seedlings.

Viability of cryopreserved zoosporangia. Plasmodia or zoosporangia were observed in roots of all inoculated nightshade seedlings 14 days following inoculation of healthy nightshade roots with thawed roots containing zoosporangia of each of isolates PA-1 and NB-1 of S. subterranea f. sp. subterranea, regardless of whether the duration of cryopreservation of the zoosporangia at $-80^{\circ} \mathrm{C}$ was 1 week, 1 month, or 6 months. This indicated that after storage at $-80^{\circ} \mathrm{C}$ for 6 months, the thawed zoosporangia released zoospores that were viable and could infect healthy nightshade roots.

Verification of S. subterranea f. sp. subterranea-specific RFLP markers. Eight reproducible, intense, and putative $S$. subterranea f. sp. subterranea-specific RAPD products were identified, cloned, and sequenced from the RAPD assays. These products were designated OPA $02_{650}, \mathrm{OPA} 02_{900}$, OPA02 $2_{1100}$, 
OPA05 550 , OPA05 $5_{900}$, OPA0 $_{1000}$, OPA $10_{1100}$, and OPA10 1200 , based on the primer used and the size of the DNA fragment. All products except OPA $10_{1100}$ showed hybridization signals for DNA isolated from cystosori of the Pennsylvania and Idaho tuber samples, and for DNA isolated from nightshade roots inoculated with isolates PA-1 and ID-1 when tested as RFLP probes by Southern hybridization. No hybridization signal was detected for DNA isolated from potato, bacteria, or healthy nightshade roots. This indicated that seven probes were specific for $S$. subterranea f. sp. subterranea. Five of these probes, OPA02 650 , OPA0 $2_{1100}$, OPA $05_{550}, \mathrm{OPA}_{05} 5_{900}$, and OPA08 ${ }_{1000}$, hybridized with 5 to 30 fragments per isolate, indicating that these probes contained repetitive elements in the genome of the pathogen. Two probes, OPA $02_{900}$ and OPA $10_{1200}$, hybridized to one fragment per isolate and presumably corresponded to single-copy sequences. Database searches in GenBank using BLAST revealed no similarity of any of the seven probe sequences to known DNA sequences.

Genetic analysis of single cystosorus isolates. The seven $S$. subterranea f. sp. subterranea-specific probes were subsequently used for RFLP analysis of 24 isolates of the pathogen. Five probes, OPA $02_{1100}, \mathrm{OPA} 05_{550}, \mathrm{OPA} 05_{900}, \mathrm{OPA} 08_{1000}$, and

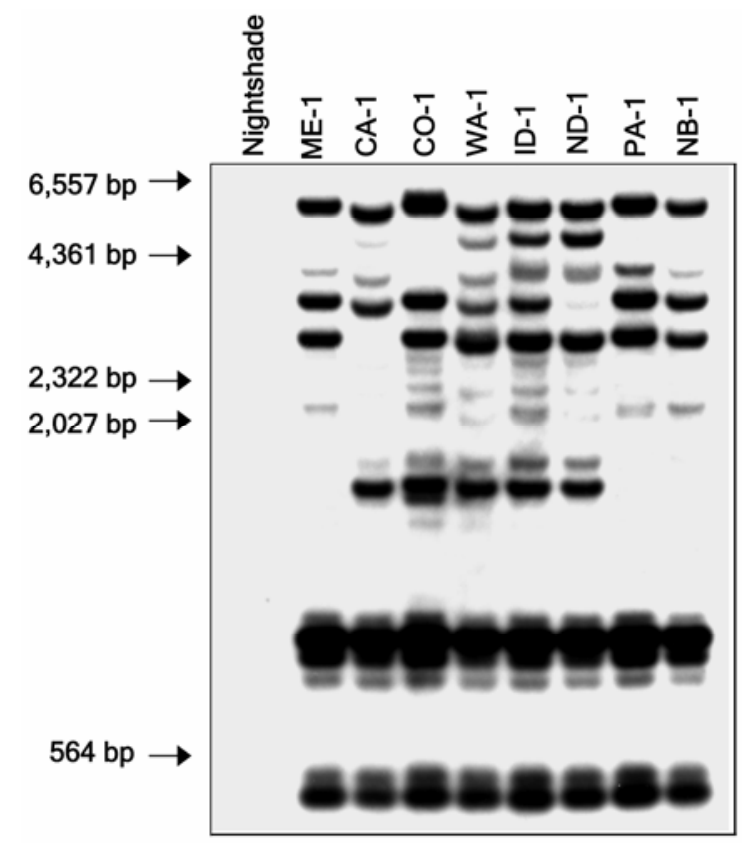

Fig. 1. Southern hybridization of EcoRI-digested DNA from eight single cystosorus isolates of Spongospora subterranea f. sp. subterranea using probe OPA08 $8_{1000}$. Nightshade DNA was used as a noninoculated control treatment. Isolate names are shown above the respective lanes. Origin of isolates: $\mathrm{CA}=$ California, $\mathrm{CO}=$ Colorado, $\mathrm{ID}=$ Idaho, $\mathrm{ME}=$ Maine, $\mathrm{NB}=$ New Brunswick in Canada, ND = North Dakota, PA $=$ Pennsylvania, and WA $=$ Washington. Molecular sizes of relevant fragments are indicated by arrows on the left.
OPA $10_{1200}$, were found to be polymorphic among isolates (Fig. 1), suggesting that these probes may be useful for DNA fingerprinting of isolates of $S$. subterranea f. sp. subterranea. Of 89 intensive DNA bands identified for 24 isolates of $S$. subterranea $\mathrm{f}$. sp. subterranea, 31 showed polymorphisms, ranging from one to nine polymorphisms per probe-enzyme combination. Genetic differences within geographic locations were not observed, as the three single cystosorus isolates from each location had identical RFLP patterns. Among locations, six distinct genotypes were found (Table 1). Isolates from Maine, New Brunswick, and Pennsylvania displayed identical fingerprints and were designated as a single type (type D). Isolates from the other five locations had distinct RFLP patterns and were designated as different types (types A, B, C, E, and F) (Table 1).

Genetic distances based on all possible pairs of isolates of S. subterranea f. sp. subterranea ranged from 0.000 to 0.0316 (Table 2). The greatest genetic distance was between the California isolates and the eastern isolates (Maine, New Brunswick, and Pennsylvania). The UPGMA analysis of the genetic relationship of the isolates based on genetic distance values resulted in two distinct clusters (I and II) (Table 1; Fig. 2). Cluster I was

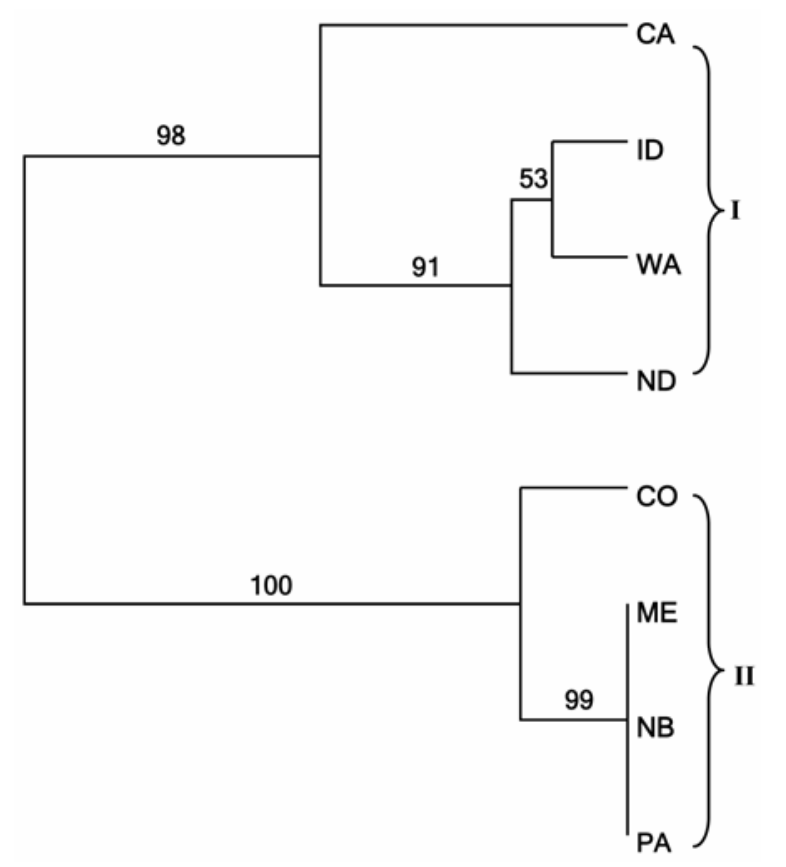

Fig. 2. Dendrogram of the genetic relationships of Spongospora subterranea f. sp. subterranea isolates from eight geographic locations constructed by the unweighted pair-group method with the arithmetic average analysis of restriction fragment length polymorphism data. Origin of isolates: $\mathrm{CA}=$ California, $\mathrm{CO}=$ Colorado, $\mathrm{ID}=$ Idaho, $\mathrm{ME}=$ Maine, $\mathrm{NB}=$ New Brunswick in Canada, $\mathrm{ND}=$ North Dakota, $\mathrm{PA}=$ Pennsylvania, and $\mathrm{WA}=$ Washington. Bootstrap values are indicated at each branch node.

TABLE 2. Genetic distance matrix generated from Nei-Li analysis of the restriction fragment length polymorphism (RFLP) data ${ }^{\mathrm{a}}$ of Spongospora subterranea $\mathrm{f}$. sp. subterranea isolates from seven states in the United States and New Brunswick, Canada

\begin{tabular}{|c|c|c|c|c|c|c|c|c|}
\hline Isolate $^{b}$ & $\mathrm{CA}$ & $\mathrm{CO}$ & ID & $\mathrm{ME}$ & NB & ND & $\mathrm{PA}$ & WA \\
\hline $\mathrm{CA}$ & 0.0000 & ... & $\ldots$ & $\ldots$ & $\ldots$ & $\ldots$ & $\ldots$ & $\ldots$ \\
\hline ID & 0.0139 & 0.0225 & 0.0000 & $\ldots$ & $\ldots$ & $\ldots$ & $\ldots$ & $\ldots$ \\
\hline ND & 0.0155 & 0.0296 & 0.0033 & 0.0269 & 0.0269 & 0.0000 & $\ldots$ & $\ldots$ \\
\hline PA & 0.0316 & 0.0046 & 0.0225 & 0.0000 & 0.0000 & 0.0269 & 0.0000 & $\ldots$ \\
\hline WA & 0.0104 & 0.0239 & 0.0033 & 0.0213 & 0.0213 & 0.0067 & 0.0213 & 0.0000 \\
\hline
\end{tabular}

${ }^{a}$ RFLP data were obtained using two restriction enzymes and five polymorphic $S$. subterranea f. sp. subterranea-specific probes.

${ }^{\mathrm{b}}$ Origin of isolates: $\mathrm{CA}=$ California, $\mathrm{CO}=$ Colorado, $\mathrm{ID}=$ Idaho, ME $=$ Maine, NB = New Brunswick in Canada, ND = North Dakota, PA = Pennsylvania, and $\mathrm{WA}=$ Washington . 
composed of isolates originating from western North America (California, Idaho, North Dakota, and Washington) except those from Colorado, with $98 \%$ bootstrap support. Cluster II was composed of isolates originating from eastern North America (Maine, New Brunswick, and Pennsylvania) as well as the isolates from Colorado, and had $100 \%$ bootstrap support.

\section{DISCUSSION}

In this study, the production of single cystosorus isolates and the development of polymorphic RFLP markers for S. subterranea f. sp. subterranea were achieved. Analysis of 24 isolates of the pathogen using RFLP markers demonstrated for the first time the occurrence of genetic variation among isolates of $S$. subterranea f. sp. subterranea from North America. Six genotypes and two major clusters were identified among these isolates.

Random clones from a genomic library of a pathogen are usually used as RFLP probes for genetic analyses (25). In the present study, RFLP markers specific for $S$. subterranea f. sp. subterranea were developed from RAPD bands. Although reproducibility of RAPD analysis is often poor due to low annealing temperatures and the presence of contaminants, RAPD products are usually repeated sequences and useful sources of polymorphic RFLP markers (46). RAPD products have been converted successfully to polymorphic RFLP markers to assess the genetic variation of other pathogens (17). In this study, five polymorphic probes specific to $S$. subterranea $\mathrm{f}$. $\mathrm{sp}$. subterranea were identified: four were moderate to highly repetitive sequences, and one was a single copy sequence. These results proved that developing polymorphic RFLP markers from RAPD bands is efficient. Despite the limited number of RFLP markers evaluated, the markers identified in this study were useful for differentiating isolates of the pathogen. These probes would also be useful for studying population structure and genome organization of $S$. subterranea $\mathrm{f}$. sp. subterranea.

RFLP probes were developed in this investigation to study the genetic variation of $S$. subterranea $\mathrm{f}$. $\mathrm{sp}$. subterranea, but not for detection of the pathogen. Therefore, the probes were not tested against other taxonomically related species. For detection of $S$. subterranea f. sp. subterranea in soil or on tubers, pathogenspecific PCR-based assays have been developed $(2,4,37)$. There are two forma speciales in $S$. subterranea: $S$. subterranea f. sp. subterranea, the cause of powdery scab of potato, and S. subterranea f. sp. nasturtii, the cause of crook root of watercress (41). Based on host specificity and morphological differences of these two forma speciales, Dick (8) recently raised this taxon to specific rank and separated them into distinct species: $S$. subterranea and $S$. nasturtii. Comparison of ITS rDNA sequences and phylogenetic analyses of $18 \mathrm{~S}$ rDNA sequences also showed that these two forma speciales are genetically distinct, and supported the view of Dick (8) that these two forma speciales should be considered separate species (35). These findings, in addition to a lack of homology between the probes and GenBank database sequences, mean that the probes developed in this study are likely specific to $S$. subterranea f. sp. subterranea.

To use RFLP analyses to study genetic variation of a pathogen, a large amount of DNA ( 3 to $5 \mu \mathrm{g}$ ) is required $(25,48)$. It is also necessary to use isolates of the pathogen derived from single spores, since spore mixtures may contain multiple genotypes. However, no method of isolation from single spores has been established for the obligate pathogen $S$. subterranea $\mathrm{f}$. sp. subterranea. To date, this pathogen has only reproduced under experimental conditions on living tissue, and the vegetative form of the pathogen outside of the host is cystosori. A single cystosorus consists of hundreds of resting spores that originated from divisions of one cell (22). In this study, nightshade seedlings were inoculated with single cystosorus, and infected roots with large amounts of plasmodia and zoosporangia were observed after three cycles of inoculation. These results indicate that inoculation with a single cystosorus for propagation of $S$. subterranea f. sp. subterranea on nightshade is efficient for extraction of a large quantity of pathogen DNA. Although the extracted DNA was a mixture of pathogen and host plant DNA, the DNA was suitable for RFLP analysis as the RFLP markers were specific to the pathogen and not the host plant DNA. The hydroponic system evaluated in this study using nightshade also showed the cycle of development (from zoospore to zoospore) of $S$. subterranea f. sp. subterranea on the host plant. Each cycle was completed in 3 to 4 days and produced more than a 10 -fold increase in numbers of zoospores. This system was easy to manipulate and will be useful for studies on zoospore biology, and the infection process and development of $S$. subterranea $\mathrm{f}$. sp. subterranea.

$S$. subterranea $\mathrm{f}$. sp. subterranea can infect nightshade roots and develop zoosporangia, which release zoospores. However, no resting spore stage of the pathogen has been found in nightshade roots (36). To maintain single cystosorus isolates, serial inoculation of nightshade roots has to be carried out every 4 days. This procedure is labor intensive and carries the risk of genetic instability. Thus, cryopreservation appears to be a logical choice for long-term storage of the isolates. Successful cryopreservation of microorganisms has been reported $(6,16)$. A simple and effective technique using glycerol as a protectant was used in this study for the relatively long-term storage of $S$. subterranea $\mathrm{f}$. sp. subterranea isolates. The cryopreserved zoosporangia were viable after storage at $-80^{\circ} \mathrm{C}$ for 6 months. The preservation and archiving of $S$. subterranea f. sp. subterranea isolates is essential for future genotypic and phenotypic comparisons.

Although RFLP genetic distances of isolates of $S$. subterranea f. sp. subterranea were low among locations and ranged from 0.000 to 0.0316 in this study, the results indicate that genetic variation exists among North American isolates of the pathogen. The ITS DNA sequences of these isolates were identical in a previous study (35). Therefore, the RFLP assays evaluated in this study displayed a greater potential for differentiation of the pathogen than ITS sequence analysis. The lack of genetic variation within locations in our study suggests genetic clonality among isolates of $S$. subterranea f. sp. subterranea from the same location. This indicates that populations of S. subterranea f. sp. subterranea causing powdery scab epidemics may have a significant clonal structure. However, the sample size in this study was small, and large numbers of isolates of $S$. subterranea $\mathrm{f}$. sp. subterranea should be assessed for a more accurate appraisal of genetic diversity within and among sites.

Cluster analysis of the RFLP data clearly separated the isolates of $S$. subterranea $\mathrm{f}$. sp. subterranea into two major genotypic groups. The separation of all western isolates except those from Colorado, from the eastern isolates suggests that the North American population of $S$. subterranea $\mathrm{f}$. sp. subterranea is comprised of two distinct evolutionary lineages that are genetically isolated. The existence of two distinct lineages of $S$. subterranea $\mathrm{f}$. sp. subterranea in North America may perhaps be explained by the spread of the pathogen on seed tubers.

$S$. subterranea f. sp. subterranea is both a seed tuber- and a soilborne pathogen. Infected or contaminated seed tubers are responsible for long-distance spread of the pathogen (19). Powdery scab was believed to have been introduced on potato seed pieces from Europe to Canada and the United States, and subsequently spread across the United States and Canada on seed (12,26,27, 39). The first report of powdery scab in North America was in Canada in the provinces of Nova Scotia, New Brunswick, Quebec, Ontario, and Alberta in 1913 (12). That same year, Melhus (26) identified powdery scab in northern Maine. Powdery scab was found in 1914 in two counties of New York, and by 1915 in the Tillamook area of Oregon, the Snohomish area of Washington, and two counties in Minnesota (27,31). By 1923, powdery scab was established in Pennsylvania and most of the 
New England states as well as most northern states across the United States (39). In the eastern United States, most of the potato seed production takes place in Maine, from where seed tubers are shipped throughout the eastern states. Therefore, the powdery scab population on the east coast probably originated from Maine. This may explain why isolates of the pathogen from eastern potato seed lots have identical genotypes. The seed in the western states originates from western seed production areas, which would account for a western clonal population that is distinct from the eastern population. The fact that the Colorado isolates are more similar to the eastern population can perhaps be explained by the fact that recent introduction of new potato cultivars into Colorado may have been from seed produced in eastern Canada. While our results suggest that $S$. subterranea f. sp. subterranea is comprised of two major groups that are genetically isolated in North America, the numbers and sources of isolates are limited in this investigation. Since seed movement most likely played a large role in dissemination of powdery scab and will continue to do so, further research is needed to study the genetic structure of populations of $S$. subterranea $\mathrm{f}$. sp. subterranea by using more isolates from different regions and originating from different potato cultivars.

In recent years, powdery scab has become a major concern to potato growers in the United States and Europe $(5,43)$ and has become increasingly important in potato breeding programs $(14,34)$. Genetic characterization of $S$. subterranea $\mathrm{f}$. sp. subterranea is therefore important for effective and durable deployment of powdery scab resistant potato cultivars. However, little is known about the genetic structure of populations of this pathogen. Screening of potato germ plasm for resistance to the pathogen often occurs in only one or few locations with unknown pathogen genotypes in those locations. Recently, in screening potato cultivars for resistance to powdery scab, Merz et al. (29) found different reactions of some potato cultivars to cystosori inoculum originating from different locations. They suggested that genetic analysis of pathogenic variation of $S$. subterranea $\mathrm{f}$. sp. subterranea is urgently needed. In this study, different genotypes and two major clusters of isolates of $S$. subterranea f. sp. subterranea were identified in North America. These findings are important for the design of plant breeding programs to test for resistance to powdery scab.

While powdery scab of potato is an important disease throughout the world, the causal organism is a soilborne obligate pathogen that has not been cultured in vitro, so research on the disease has progressed slowly. The techniques developed in this study, i.e., production of single cystosorus isolates of $S$. subterranea $\mathrm{f}$. sp. subterranea and development of polymorphic RFLP markers for this pathogen, provide further tools to study powdery scab of potato.

\section{ACKNOWLEDGMENTS}

This research was supported by a grant from the USDA-ARS Potato Program.

\section{LITERATURE CITED}

1. Altschul, S. F., Madden, T. L., Schäffer, A. A., Zhang, J., Zhang, Z., Miller, W., and Lipman, D. J. 1997. Gapped BLAST and PSI-BLAST: A new generation of protein database search programs. Nucleic Acids Res. 25:3389-3402.

2. Bell, K. S., Roberts, J., Verrall, S., Cullen, D. W., Williams, N. A., Harrison, J. G., Toth, I. K., Cooke, D. E. L., Duncan, J. M., and Claxton, J. R. 1999. Detection and quantification of Spongospora subterranea $\mathrm{f}$. sp. subterranea in soils and on tubers using specific PCR primers. Eur. J. Plant Pathol. 105:905-915.

3. Böning, K., and Wallner, F. 1938. Beobachtungen und Versuche zur Frage der Widerstandsfähigkeit der Kartoffelsorten gegen Schort. Prakt. Bl. Pflanzenb. 15:268-279.

4. Bulman, S. R., and Marshall, J. W. 1998. Detection of Spongospora subterranea in potato tuber lesions using the polymerase chain reaction
(PCR). Plant Pathol. 47:759-766.

5. Christ, B. J. 2002. Is powdery scab a new concern? Valley Potato Grower, March:26-27.

6. Dahmen, H., Staub, T., and Schwinn, F. J. 1983. Technique for long-term preservation of phytopathogenic fungi in liquid nitrogen. Phytopathology 73:241-246.

7. de Boer, R. F. 2000. Research into the biology and control of powdery scab of potatoes in Australia. Pages 79-83 in: Proceedings of the First European Powdery Scab Workshop. U. Merz and A. K. Lees, eds. SCRI, Dundee, U.K.

8. Dick, M. W. 2001. Straminipilous Fungi. Kluwer Academic Publishers, London.

9. Doyle, J. J., and Doyle, J. L. 1990. Isolation of plant DNA from fresh tissue. Focus 12:13-15.

10. Fahling, M., Graf, H., and Siemens, J. 2004. Characterization of a singlespore isolate population of Plasmodiophora brassicae resulting from a single club. J. Phytopathol. 152:438-444.

11. Felsenstein, J. 1985. Confidence limits on phylogenies: An approach using the bootstrap. Evolution 39:783-791.

12. Güssow, H. T. 1913. Powdery scab of potatoes Spongospora subterranea (Wallr.) Johns. Phytopathology 3:18-19.

13. Harrison, J. G., Searle, R. J., and Williams, N. A. 1997. Powdery scab disease of potato-A review. Plant Pathol. 46:1-25.

14. Haynes, K. G., Porter, G. A., Christ, B. J., Goth, R. W., DeLong, K. O., Halseth, D. E., Sieczka, J. B., Henninger, M. R., Sterrett, S. B., Yencho, G. C., and Webb, R. E. 2001. Amey: A multipurpose, russet-skinned potato cultivar for the eastern United States. Am. J. Potato Res. 78:175181.

15. Hims, M. 1976. The weather relationships of powdery scab disease of potatoes. Ann. Appl. Biol. 84:274-275.

16. Hubálek, Z. 2003. Protectants used in the cryopreservation of microorganisms. Cryobiology 46:205-229.

17. Jiménez-Gasco, M. M., Milgroom, M. G., and Jiménez-Díaz, R. M. 2004. Stepwise evolution of races in Fusarium oxysporum f. sp. ciceris inferred from fingerprinting with repetitive DNA sequences. Phytopathology 94:228-235.

18. Jones, R. A. C., and Harrison, B. D. 1969. The behaviour of potato moptop virus in soil, and evidence for its transmission by Spongospora subterranea (Wallr.) Lagerh. Ann. Appl. Biol. 63:1-17.

19. Karling, J. S. 1968. The Plasmodiophorales. 2nd ed. Hafner Publishing Co., New York.

20. Khrobrykh, N. D. 1938. Virus and bacterial diseases of plants, the biological, the chemical, and the mechanical methods of plant protection. Pages 27-30 in: Summary of the Scientific Research Work of the Institute of Plant Protection (Leningrad) for the Year 1936. (Abstr.) Rev. Appl. Mycol. 18:378.

21. Klewer, A., Luerben, H., Graf, H., and Siemens, J. 2001. Restriction fragment length polymorphism markers to characterize Plasmodiophora brassicae single-spore isolates with different virulence patterns. J. Phytopathol. 149:121-127.

22. Kole, A. P. 1954. A contribution to the knowledge of Spongospora subterranea (Wallr.) Lagerh., the cause of powdery scab of potatoes. Tijd. Plantenz. 60:1-65.

23. Lambert, D. H., Levy, L., Mavrodieva, V. A., Johnson, S. B., Babcock, M. J., and Vayda, M. E. 2003. First report of potato mop-top virus on potato from the United States. Plant Dis. 87:872.

24. Marmur, J. 1961. A procedure for the isolation of deoxyribonucleic acid from micro-organisms. J. Mol. Biol. 3:208-218.

25. McDonald, B. A., and Martinez, J. P. 1990. Restriction fragment length polymorphisms in Septoria tritici occur at a high frequency. Curr. Genet. 17:133-138.

26. Melhus, I. E. 1913. The powdery scab of potato (Spongospora solani) in Maine. Science 38:132-133.

27. Melhus, I. E., Rosenbaum, J., and Schultz, E. S. 1916. Spongospora subterranea and Phoma tuberosa on the Irish potato. J. Agric. Res. 7:213-254.

28. Merz, U. 1989. Infectivity, inoculum density and germination of Spongospora subterranea resting spores: A solution-culture test system. EPPO Bull. 19:585-592.

29. Merz, U., Martinez, V., and Schwärzel, R. 2004. The potential for the rapid screening of potato cultivars (Solanum tuberosum) for resistance to powdery scab (Spongospora subterranea) using a laboratory bioassay. Eur. J. Plant Pathol. 110:71-77.

30. Möller, M., and Harling, R. 1996. Randomly amplified polymorphic DNA (RAPD) profiling of Plasmodiophora brassicae. Lett. Appl. Microbiol. 22:70-75.

31. Moose, W. J. 1914. Powdery scab of potatoes. Maine AES Bull. 227:89104.

32. Nei, M., and Li, W. H. 1979. Mathematical model for studying genetic variation in terms of restriction endonucleases. Proc. Natl. Acad. Sci. USA 76:5269-5273. 
33. Osborn, T. G. B. 1911. Spongospora subterranea (Wallroth) Johnson. Ann. Bot. 25:327-341.

34. Porter, G. A., Lambert, D. H., Bushway, A. A., Plaisted, R. L., Paddock, K. M., DeJong, W. S., and Halseth, D. E. 2004. Monticello: A mid-season variety with good tuber appearance and chipping potential from mid- to long-term storage. Am. J. Potato Res. 81:143-152.

35. Qu, X. S., and Christ, B. J. 2004. Genetic variation and phylogeny of Spongospora subterranea f. sp. subterranea based on ribosomal DNA sequence analysis. Am. J. Potato Res. 81:385-394.

36. Qu, X. S., and Christ, B. J. The host range of Spongospora subterranea $\mathrm{f}$. sp. subterranea in the United States. Am. J. Potato Res. (In press.)

37. Qu, X. S., Kavanagh, J. A., Egan, D., and Christ, B. J. 2006. Detection and quantification of Spongospora subterranea $\mathrm{f}$. sp. subterranea by PCR in host tissue and naturally infested soils. Am. J. Potato Res. 83:21-30.

38. Qu, X. S., Kavanagh, J. A., Egan, D., and Lahert, H. 2001. Studies on amoebae and cysts associated with the isolation of Spongospora subterranea f. sp. subterranea in vitro. Plant Pathol. 50:420-426.

39. Shapovalov, M. 1923. Relation of potato skinspot to powdery scab. J. Agric. Res. 23:285-294.

40. Sukno, S. A., Taylor, A. M., and Farman, M. L. 2002. Development of contamination-free restriction fragment length polymorphism probes for the obligate biotroph Peronospora tabacina, an oomycete causing blue mold of tobacco. Phytopathology 92:1227-1235.

41. Tomlinson, J. A. 1958. Crook root of watercress. III, The causal organism
Spongospora subterranea (wallr.) Lagerh. f. sp. nasturtii f. sp. nov. Trans. Br. Mycol. Soc. 41:491-498.

42. van de Graaf, P., Lees, A. K., Wale, S. J., and Duncan, J. M. 2005. Effect of soil inoculum level and environmental factors on potato powdery scab caused by Spongospora subterranea. Plant Pathol. 54:22-28.

43. Wale, S. J. 2000. Summary of the session on national potato production and the powdery scab situation. Pages 3-9 in: Proceedings of the First European Powdery Scab Workshop. U. Merz and A. K. Lees, eds. SCRI, Dundee, U.K.

44. Wangsomboondee, T., Groves, C. T., Shoemaker, P. B., Cubeta, M. A., and Ristaino, J. B. 2002. Phytophthora infestans populations from tomato and potato in North Carolina differ in genetic diversity and structure. Phytopathology 92:1189-1195.

45. Weising, K., Nybom, H., Wolff, K., and Meyer, W. 1995. DNA fingerprinting in plants and fungi. CRC Press, Boca Raton, FL.

46. Williams, J. G. K., Kubelik, A. R., Livak, K. J., Rafalski, J. A., and Tingey, S. V. 1990. DNA polymorphisms amplified by arbitrary primers are useful as genetic markers. Nucleic Acids Res. 18:6531-6535.

47. Würzer, B. 1964. Ergäzende Untersuchungen über den Pulverschorf der Kartoffel und dessen Erreger Spongospora subterranea (Wallr.) Lagerh. diss. Landwirtschaftliche Hochschule, Hohenheim, Germany.

48. Zhan, J., Mundt, C. C., and McDonald, B. A. 2001. Using restriction fragment length polymorphisms to assess temporal variation and estimate the number of ascospores that initiate epidemics in field populations of Mycosphaerella graminicola. Phytopathology 91:1011-1017. 